
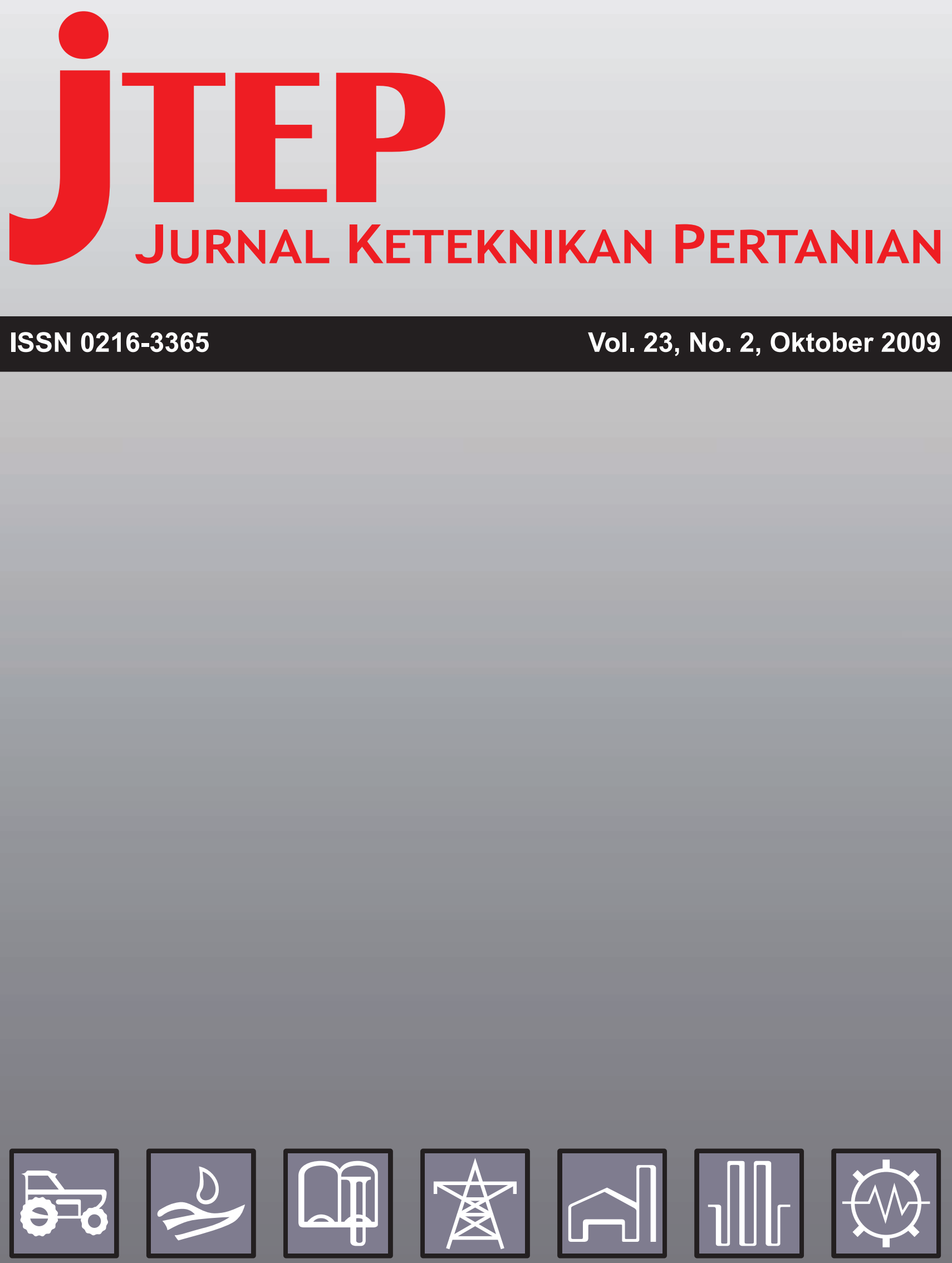

\title{
Publikasi Resmi
}

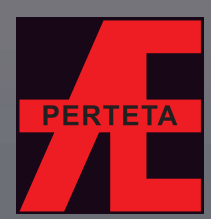

Perhimpunan Teknik Pertanian Indonesia (Indonesian Society of Agricultural Engineering) bekerjasama dengan

Departemen Teknik Pertanian - FATETA Institut Pertanian Bogor 


\section{jTEP JURNAL KeteKnIKAN PERTANIAN}

Jurnal Keteknikan Pertanian merupakan publikasi resmi Perhimpunan Teknik Pertanian Indonesia (PERTETA) yang didirikan 10 Agustus 1968 di Bogor, berkiprah dalam pengembangan ilmu keteknikan untuk pertanian tropika dan lingkungan hayati. Jurnal ini diterbitkan dua kali setahun. Penulis makalah tidak dibatasi pada anggota PERTETA tetapi terbuka bagi masyarakat umum. Lingkup makalah, antara lain: teknik sumberdaya lahan dan air, alat dan mesin budidaya, lingkungan dan bangunan, energi alternatif dan elektrifikasi, ergonomika dan elektronika, teknik pengolahan pangan dan hasil pertanian, manajemen dan sistem informasi. Makalah dikelompokkan dalam invited paper yang menyajikan isu aktual nasional dan internasional, review perkembangan penelitian, atau penerapan ilmu dan teknologi, technical paper hasil penelitian, penerapan, atau diseminasi, serta research methodology berkaitan pengembangan modul, metode, prosedur, program aplikasi, dan lain sebagainya. Pengiriman makalah harus mengikuti panduan penulisan yang tertera pada halaman akhir atau menghubungi redaksi via telpon, faksimili atau e-mail. Makalah dapat dikirimkan langsung atau via pos dengan menyertakan hard- dan soft-softcopy, atau e-mail. Penulis tidak dikenai biaya penerbitan, akan tetapi untuk memperoleh satu eksemplar dan 10 re-prints dikenai biaya sebesar Rp 50.000. Harga langganan Rp 70.000 per volume (2 nomor), harga satuan Rp 40.000 per nomor. Pemesanan dapat dilakukan melalui e-mail, pos atau langsung ke sekretariat. Formulir pemesanan terdapat pada halaman akhir.

\section{Penanggungjawab:}

Ketua Perhimpunan Teknik Pertanian Indonesia

Ketua Departemen Teknik Pertanian, Fakultas Teknologi Pertanian, IPB

\section{Dewan Redaksi:}

Ketua : Asep Sapei

Anggota : Kudang B. Seminar

Daniel Saputra

Bambang Purwantana

Y. Aris Purwanto

\section{Redaksi Pelaksana:}

$\begin{array}{ll}\text { Ketua } & \text { : Rokhani Hasbullah } \\ \text { Sekretaris } & \text { : Satyanto K. Saptomo } \\ \text { Bendahara } & : \text { Emmy Darmawati } \\ \text { Anggota } & : \text { Usman Ahmad } \\ & \text { I Wayan Astika } \\ & \text { M. Faiz Syuaib } \\ & \text { Ahmad Mulyawatullah }\end{array}$

\section{Penerbit:}

Perhimpunan Teknik Pertanian Indonesia (PERTETA) bekerjasama dengan Departemen Teknik Pertanian, IPB Bogor

\section{Alamat:}

Jurnal Keteknikan Pertanian, Departemen Teknik Pertanian, Fakultas Teknologi Pertanian,

Kampus IPB Darmaga, Bogor 16680. Telp. 0251-8624691, Fax 0251-8623026,

E-mail: jtep@ipb.ac.id atau jurnaltep@yahoo.com. Website: ipb.ac.id/ jtep.

\section{Rekening:}

BRI, KCP-IPB, No.0595-01-003461-50-9 a/n: Jurnal Keteknikan Pertanian

\section{Percetakan:}

PT. Binakerta Adiputra, Jakarta 


\section{Ucapan Terima Kasih}

Redaksi Jurnal Keteknikan Pertanian mengucapkan terima kasih kepada para Mitra Bestari yang telah menelaah (mereview) naskah pada penerbitan Vol. 23 No. 2 Oktober 2009. Ucapan terima kasih disampaikan kepada Prof.Dr.Ir. Hadi K. Purwadaria, M.Sc (Departemen Teknik Pertanian - IPB), Prof.Dr.Ir. Tineke Mandang, MS (Departemen Teknik Pertanian - IPB), Prof.Dr.Ir. Daniel Saputra, MS (PS. Teknik Pertanian - Universitas Sriwijaya), Prof.Dr.Ir. R.A. Bustomi Rosadi, MS (Departemen Teknik Pertanian Universitas Lampung), Dr.Ir. M. Agita Tjandra, Phd (Departemen Teknik Pertanian - Universitas Andalas), Dr. Ir. Bambang Dwi Argo, DEA (Departemen Teknik Pertanian - Universitas Brawijaya Malang), Dr.Ir. Hermantoro, (INSTIPER Yogyakarta), Dr.Ir. Bambang Purwantana (Departemen Teknik Pertanian - UGM), Dr.Ir. Sigit Supadmo Arif, M.Eng (Departemen Teknik Pertanian - UGM), Dr.Ir. Astu Unadi (Kepala Balai Besar Pengembangan Mekanisme Pertanian - UGM), Dr.Ir. Haryadi Halid (Departemen IImu dan Teknologi Pangan - IPB), Dr.Ir. Yuli Suharnoto, M.Eng (Departemen Teknik Pertanian - IPB), Dr.Ir. Rokhani Hasbullah, M.Si (Departemen Teknik Pertanian - IPB), Dr.Ir. Usman Ahmad, M.Agr (Departemen Teknik Pertanian IPB), Dr.Ir. Leopold Nelwan, M.Si (Departemen Teknik Pertanian - IPB), Dr.Ir. Sutrisno, M.Agr (Departemen Teknik Pertanian IPB), Dr.Ir. Roh Santoso Budi Waspodo, MT (Departemen Teknik Pertanian - IPB), Dr.Ir. Y. Aris Purwanto, M.Sc (Departemen Teknik Pertanian - IPB), Dr.Ir. Satyanto Krido Saptomo, M.Si STP (Departemen Teknik Pertanian - IPB), 


\title{
Urban Water Demand on Interbasin Water Resources Management System
}

\author{
Kebutuhan Air Perkotaan Berbasis Pengelolaan Air Lintas Sungai
}

Sutoyo $^{1}$, M. Yanuar J. Purwanto², Kato Tasuku³, Goto Akira ${ }^{4}$

\begin{abstract}
Cidanau watershed in West of Java has 22,620 ha; it provides water for other basin in the largest industrial city of Cilegon. To have future condition of water supply and demand for Cidanau and Cilegon region model was developed expressing water supply from Cidanau built by tank model with some land uses related parameters. Water supply from Cidanau watershed depends on land use and water system in the watershed. The rest of water flow to the downstream and be utilized to the Cilegon city by Cinangka pump station and calculated based on the water use of industrial and domestic. To maintain and increase the availability of water, it is necessary to change some land uses into forest and install better water supply system with higher efficiencies. Water availability of runoff under existing condition as Scenario 1 is only sufficient until before the year 2018. Scenario 2 with the land use to be change as $50 \%$ of the mixed agricultural dry land system into forest area and $50 \%$ garden into rice field, water availability will be sufficient until more than 2018. If Scenario 2 was used together with Scenario 3 having better efficient technology, water supply will be sufficient until more than the year 2025.
\end{abstract}

Keywords : water supply, water demand, urban, interbasin, system dynamics

Diterima: 7 Januari 2009; Disetujui: 14 Juli 2009

\section{Introduction}

In water resources management the efficient utilization of water resources is the important criteria. Various water demand such as industry, agriculture, and settlement. Industrial, agricultural land, residential areas from year to year are increasing, so the competition water allocation is the most crucial problem. In interbasin water management, Cidanau watershed provides raw water for Cilegon city of other basin area of Cidanau watershed. PT. KTI processes the raw water before deliver to the Cilegon city to fulfill the increased water demand in the Cilegon area. The raw water is use for resident and industry water demand. The water availability of from Cidanau watershed is also limited. The water balance between supply and demand has to be considering for the sustainable of water resources management. More over, the degradation of watershed will affect to the temporal water distribution in the annual discharge. Adynamic analysis is required for evaluating any counter measure needed for fulfills the balance of supply and demand in the long period.

The objective of this study is to develop water management model especially water balance model based on supply-demand analysis of the interbasin Cidanau-Cilegon system for industrial urban water demand.

\section{Water Demand}

Domestic water demand is equal with a total amount of water uses for total population in the city, and patterns of consumption per capita. Table 1. Shows the average daily water demand per capita for cities in developed countries. For the city in Indonesia, the level of demand for different water use is not the same and higher percentage of loss.

Winrock (1992), Directorate General of Public Work Cipta Karya set for domestic water needs of the rural community is $45 \mathrm{Icd}$ (liter capita / day) and for the city of $60 \mathrm{lcd}$. Main factors that determine the amount of water the city needs is the number of population and the accuracy of the projected population will be very important to predict the water needs in the future (Pawitan et al, 1994).

The amount of water needs for each industry is not the same to the domestic. It depends on several factors, among the number of employees, work units, the length of working hours, and others. To determine the needs for industrial water supply in urban areas can be categorized into three types

\footnotetext{
Department of Civil and Environmental Engineering, Bogor Agricultural University

Faculty staff, Dept of Agricultural Engineering, Bogor Agricultural University. Email: yan_tta@yahoo.com

Faculty of Agriculture, Ibaraki University

4 Faculty of Agriculture,Utsonomiya University
} 
based on the number of usage, big industry around $151-350 \mathrm{~m}^{3} /$ hari, medium industry are around 51 $150 \mathrm{~m}^{3} /$ hari, and small industries ranging from 5 to $50 \mathrm{~m}^{3} /$ day (Purwanto, 1995).

Mathematical analogy, the ETc is crop water requirement that occur on an planted area which can be defined as the water needs on area with a population/industry. ETo is evapotranspiration actual can be defined as the average water population / industry and $\mathrm{Kc}$ is a crop coefficient as the coefficient of population/ industry, so it can be a model for the water demand of residential and industrial, such as the following (Purwanto, 1995):

$$
y p=\sum_{i=1}^{m}(P p \times P \times K A p \times C p)
$$

where :

$\mathrm{yp}=$ water demand for resident (I/day)

$\mathrm{Pp}=$ percentage social level (\%)

$\mathrm{P}=$ population resident(capita)

$\mathrm{KAp}=$ water use $(\mathrm{I} / \mathrm{capita} /$ day $)$

$\mathrm{Cp}=$ coefficien water consumption

$\mathrm{m}=$ number of equation

$\mathrm{i}=$ social level

$$
y i=\sum_{j=1}^{n}(p I \times I \times K a I \times C I)
$$

Table 1. Daily water demand per capita

\begin{tabular}{clcc}
\hline No. & Water use & Demand (gcd) & Percen total (\%) \\
\hline 1 & Household & 60 & 40 \\
2 & Commercial & 20 & 13 \\
3 & Industry & 45 & 30 \\
4 & Public & 15 & 10 \\
5 & Loss & 10 & 7 \\
\hline & Jumlah & 150 & 100 \\
\hline
\end{tabular}

Source: Gupta (1989), gcd= galon capita/day

where :

$\mathrm{yi}=$ water demand for industry (I/day)

$\mathrm{pl}=$ percentage industry type (\%)

$\mathrm{I}=$ population industry

$\mathrm{Kal}=$ water use for industry (1/industry/day)

$\mathrm{Cl}=$ coefficien industry water consumption

$\mathrm{n}=$ number of equation

$\mathrm{j}=$ industry type

\section{Water Resources Management on Watershed}

Water resources managementis the management of natural resources that can be restored such as water, soil and vegetation in a local river with the goal of improving, maintaining and protecting

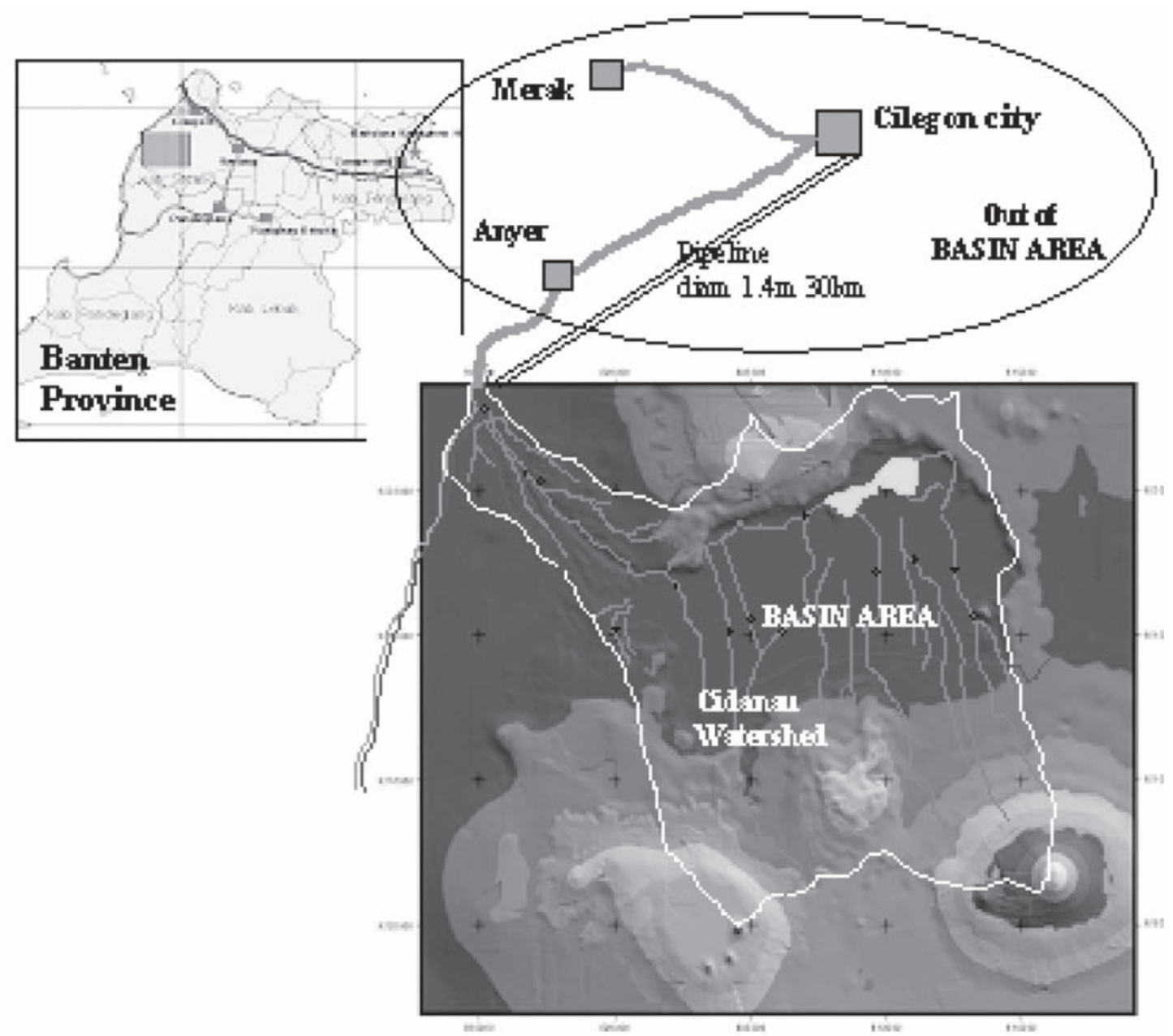

Figure 1. Location of experiment 
Table 2. Scenario of supply model

\begin{tabular}{clll}
\hline Scenario & \multicolumn{1}{c}{ Description } & $\begin{array}{c}\text { Change of } \\
\text { Minimum discharge }\end{array}$ & \multicolumn{1}{c}{ Run-off (mm) } \\
\hline 1 & Runoff $80 \%$ & $\begin{array}{l}1020 \\
\text { (Run off efficiency 0.6) }\end{array}$ \\
(Existing condition) & & $\begin{array}{l}1122 \\
\text { (Run off efficiency 0.6) }\end{array}$ \\
2 & $50 \%$ mixed agricultural \\
(Harmailis, 2001) & $\begin{array}{l}\text { dry land system into forest } \\
3\end{array}$ & $\begin{array}{l}50 \% \text { garden into rice field } \\
\text { Pipeline canals of existing condition }\end{array}$ & (Run off efficiency 0.9) \\
\hline
\end{tabular}

the flow of the river in order to produce water for agricultural interests, the needs of the population, industry, energy power, and recreation (Manan, 1979). The objective of the management of water resources in the watershed is the watershed as a whole that can provide benefits for sustainable human beings in life and meets the needs of life and prosperity (Soerianegara, 1978). The action of water resources management, depend on the problems faced by the watershed. If the problem is the lack of water supply - supply is smaller than demand then the action must be done is take the additional water supply. On the other hand, if the problem is too much water supply - supply is greater than demand - then the action must be done is to seek optimum the utilization of excess supply available. The basis of every action is the management of water resources to balance the demand and supply side (water balance) (Dumairy, 1992). Furthermore it is said by Dumairy (1992), that any principal problems that must be faced with the detailed, so
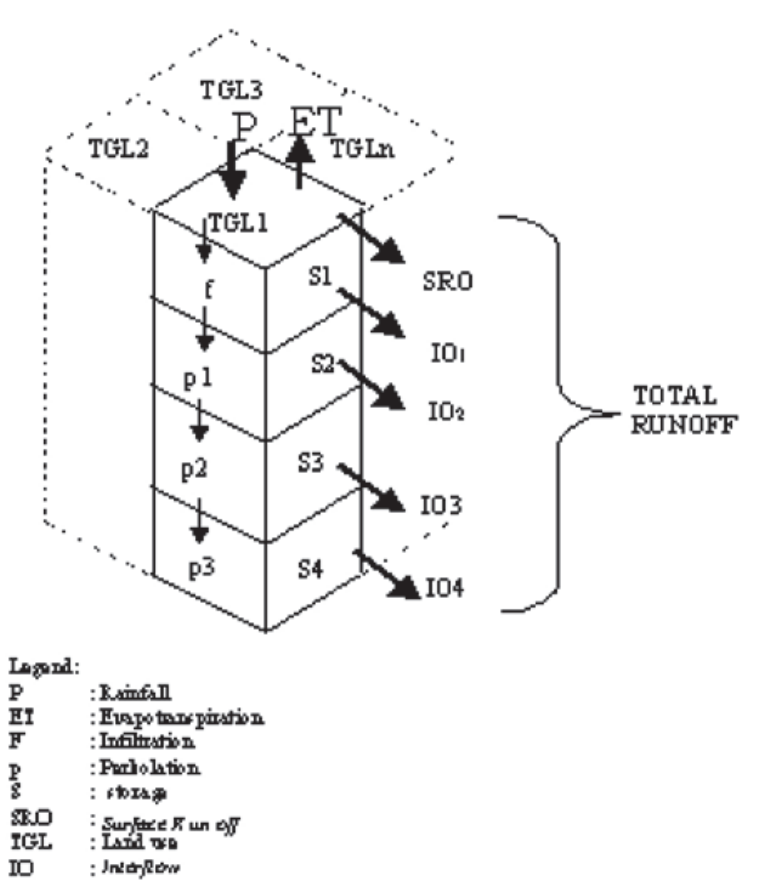

Figure 2. Configuration of tank model on watershed that the form of concrete actions that can be taken implemented. If the problem is the lack of supply of water resources, so must be clear of water supply and demand for what is the gap / imbalance is, whether for irrigation, for industrial purposes, or for domestic purposes. Need further detail investigation on lack of water supply, whether due to natural supply is not sufficient for quantitative, or because the quality of water available is not eligible to be used (Harmailis, 2001).

\section{Methodology}

\section{Water Supply Model}

Cidanau watershed is divided into four tanks based on land use. The first tank is the Swamp Lake, the second tank is a forest area (upstream), the third tank is a tank area of plantation and the fourth is a rice field. The division of the tank area by land use, and rainfall based on the Thiessen polygon.

\section{Tank Model Structure}

According to Figure 2, equation from the top of the tank:

$$
\begin{aligned}
\partial x_{1}(t) / \partial t= & a_{1}\left\{x_{1}(t)-h a_{1}\right\}+b\left\{x_{1}(t)-h_{5}\right\} \\
& +z_{1} x_{1}(t)-C H+E T c(t)
\end{aligned}
$$

And for the other tanks $(i=2-4, z 4=0$ ) equation is:

$$
\begin{aligned}
\partial x_{i}(t) / \partial t= & a_{i}\left\{x_{i}(t)-h a_{i}\right\}+z_{i} \cdot x_{i}(t) \\
& -z_{i-1} \cdot x_{i-1}(t)
\end{aligned}
$$

River Discharge (Q) was calculated by

$$
Q=b\left\{x_{1}(t)-h_{5}\right\}+\sum a_{i}\left\{x_{i}(t)-h a_{i}\right\}
$$

\section{Water Supply Prediction}

Prediction of water availability in the future can be done by applying a supply model. Discharge of water can be produced with the input data are daily rainfall and daily data evapotranspirasi. Predicted rain for the future is difficult to determined exactly and precisely. One way that can be done is to use hydrology analyses of rain events will result in $80 \%$. 

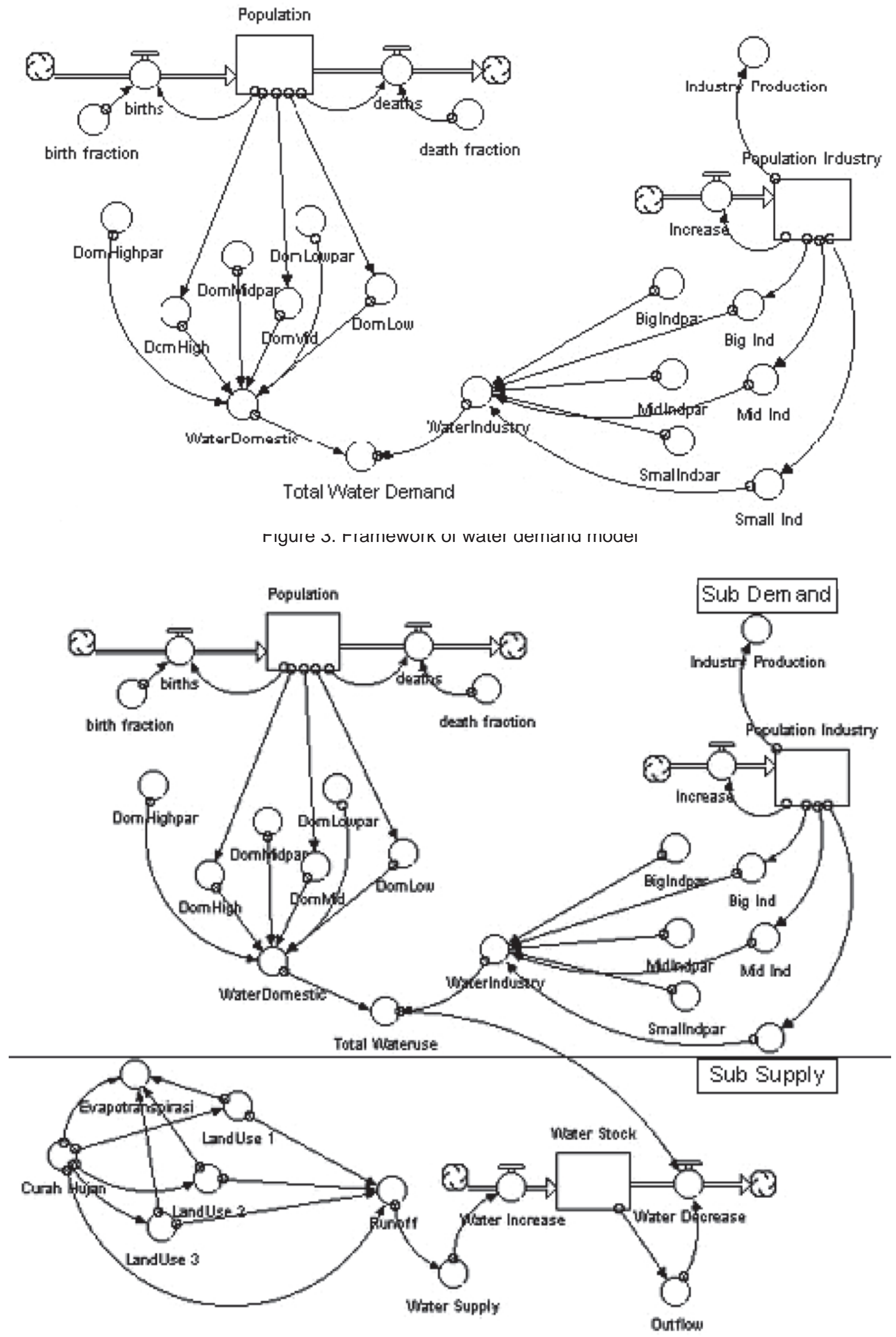

Figure 4. Framework of Supply-Demand Model] 
Rainfall data with the chance of rainfall are $80 \%$ calculated from data from the annual rainfall in the watershed Cidanau for 10 years (1993-2002) with the help of software Rainbow, and the amount of annual rainfall. Daily rainfall data with the annual amount of rainfall that approached the amount of annual rainfall data from the Rainbow used as inputs in the model the availability of water. Results debit model the availability of water and then used as input in the program Stella to evaluate for water availability and demand by region.

Prediction of availability of water for the area used scenario land use changes. Harmailis (2001) made several scenarios land use change for the fluctuation discharge Cidanau River outlet. For DAS Cidanau will be 3 scenarios (Table 2) as a basis to simulate the availability of water coming from the watershed Cidanau.

\section{Water Demand Model}

Mathematical equation model for water demand built on the equation (3) the water demand model of the population and equation (4) the water demand of industry. Model for the water demand of domestic population consists of several parameters, the percentage of social level population, the number of population, the water needs of the average population and the constant of the respective social level. Model of the water demand of industry consists of several parameters, the percentage of type of industry, the number of industries, the water needs of the industry average and the constant of each type of industry.

Calculation model of water demand can be made using the Stella. Water is a basic essential need for the needs of the population and also the needs of industry. Population growth and a dynamic industry in line with the fulfillment of basic needs of water can be calculated using the Stella.

Model built with the framework that are mathematically related of the needs of water and then simulated so that the output form of the water demand for years to come. Framework can be seen in Figure 3.

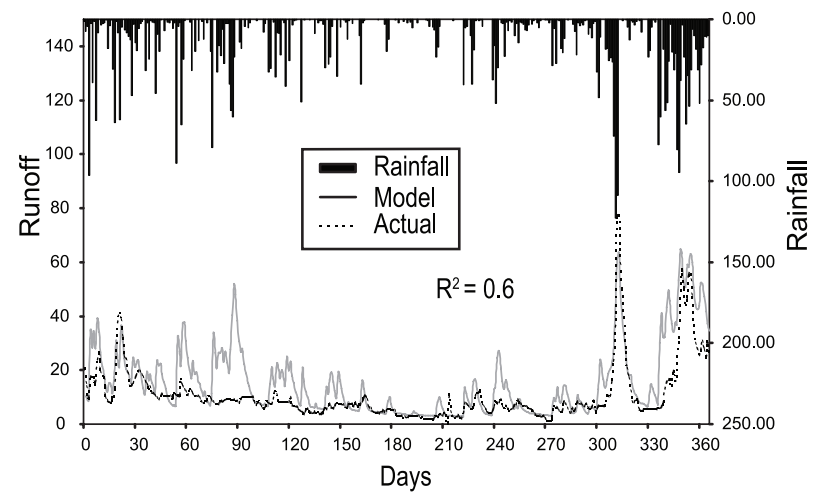

[

Figure 5. Graph calibration of model supply]

\section{Supply-Demand Water in the Future}

Development of the community not only related to population growth but must also be followed by the adequate of employment. Increasing of employment is subject to the availability of water storage. Water is needed to operate the sector of employment and meet the needs of domestic water in the area. The success of the development community on region occurred when the water for domestic and employment available, so that the predicted water demand become important in the development of the regional planning. Prediction of water supply and demand can be made using the Stella. Model built with the framework is related mathematically from model the supply and demand simulated, so that the output of Supply-Demand water for years. Framework can be seen in Figure 4.

\section{Results and Discussion}

\section{Validity of Model Supply}

Using the daily rainfall and evapotranspiration data of 1996 performed calibration of the model. After obtaining the result in the form of simulation debit, trial and error method for the calibration parameters was carried out. The coefficient values were changed until the value of the simulation debit approaching the actual debit. Show in Figure 5 and 6.

\section{Water Supply Prediction for Future}

To predict the debit years to come based on the analysis of annual rainfall for 10 years. Results predicted rain event with the potential $80 \%$ obtained a number of annual rainfall $2517 \mathrm{~mm} /$ year. Years with rainfall close to the potential rainfall data are 1998, so that the debit input availability of water for years to come use the data. Daily data in 1998 in the form of evapotranspitration data and rainfall data used as input model supply so that the results obtained debit annual volume of $1020 \mathrm{~mm}$ with a maximum of debit $22.01 \mathrm{~m}^{3} / \mathrm{det}$, debit a minimum of 3.44 and debit $\mathrm{m}^{3} /$ det an average of $6.75 \mathrm{~m}^{3} /$ det.

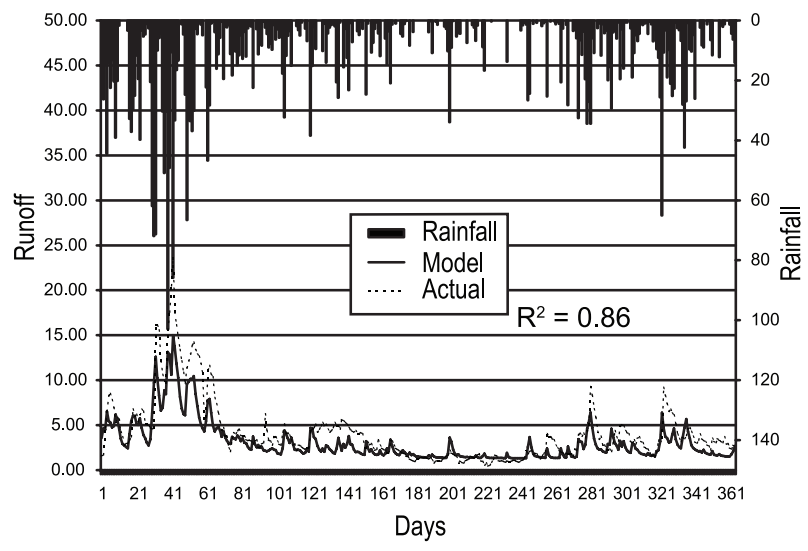

Figure 6. Graph validation of model supply 
Table 3. Result of calibration model demand for domestic

\begin{tabular}{ccccccc}
\hline Year & Cp high & Cp middle & Cp low & $\begin{array}{c}\text { Model Demand } \\
(1 / \text { day })\end{array}$ & $\begin{array}{c}\text { Demand Actual } \\
\text { (1/day) }\end{array}$ & Efficiency \\
\hline 1998 & 0.5 & 0.44 & 0.07 & 4170981 & 4347003 & 0.995 \\
1999 & 0.5 & 0.44 & 0.07 & 4550053 & 5142728 & \\
2000 & 0.5 & 0.44 & 0.07 & 5336867 & 5420920 & \\
\hline
\end{tabular}

Tabel 4. Result of calibration model demand for industry

\begin{tabular}{ccccccc}
\hline Year & $\begin{array}{c}\text { CI } \\
\text { big }\end{array}$ & $\begin{array}{c}\text { CI } \\
\text { middle }\end{array}$ & $\begin{array}{c}\text { CI } \\
\text { small }\end{array}$ & $\begin{array}{c}\text { Model demand } \\
(1 / \text { day })\end{array}$ & $\begin{array}{c}\text { Demand Actual } \\
(1 / \text { day })\end{array}$ & Efficiency \\
\hline 1998 & 13.75 & 15.17 & 14.05 & 121676940 & 83808080 & 0.941 \\
1999 & 13.75 & 15.17 & 14.05 & 100272018 & 97119850 & \\
2000 & 13.75 & 15.17 & 14.05 & 92523985 & 90677180 & \\
\hline
\end{tabular}

\section{Validity of Model Demand}

Calibration is done with the current data year 1998-2000 (3 years), to explore the value of coefficient of water needs of the population coefficient $(\mathrm{Cp})$ and the water industry needs coefficients $(\mathrm{Cl})$. Three years of data will result in three of the water needs for the population and also for three of the water needs of industry. Calibration is done with the least square method by The Eureka solver software Ver 1.0. Results of calibration model demand of the population values for the coefficients Cp level high social value 0.5 , for the coefficients Cp level middle social 0.44 , for the coefficients $\mathrm{Cp}$ level low value of 0.07 . Results of calibration model demand of industrial values for the $\mathrm{Cl}$ coefficients of the big industry $13.75, \mathrm{Cl}$ coefficients for the middle industry were valued coefficients to 15.17 and $\mathrm{Cl}$ small industries 14.05 .

Validation is done with the data of 2001 data for the water needs of the population and also the data needs of the water industry. Validation is done by using the equations of the results of calibration coefficient values of the parameters. Results validate the model needs the amount of water for the population in 2001 amounted to $11680 \mathrm{~m}^{3}$, while for the water needs of the industry amounted to $95567 \mathrm{~m}^{3}$.

\section{Supply-Demand Water in Interbasin System}

Along with the growing number of people also increases the fulfillment of life. Fulfillment does not live apart from the goods and the industry forward

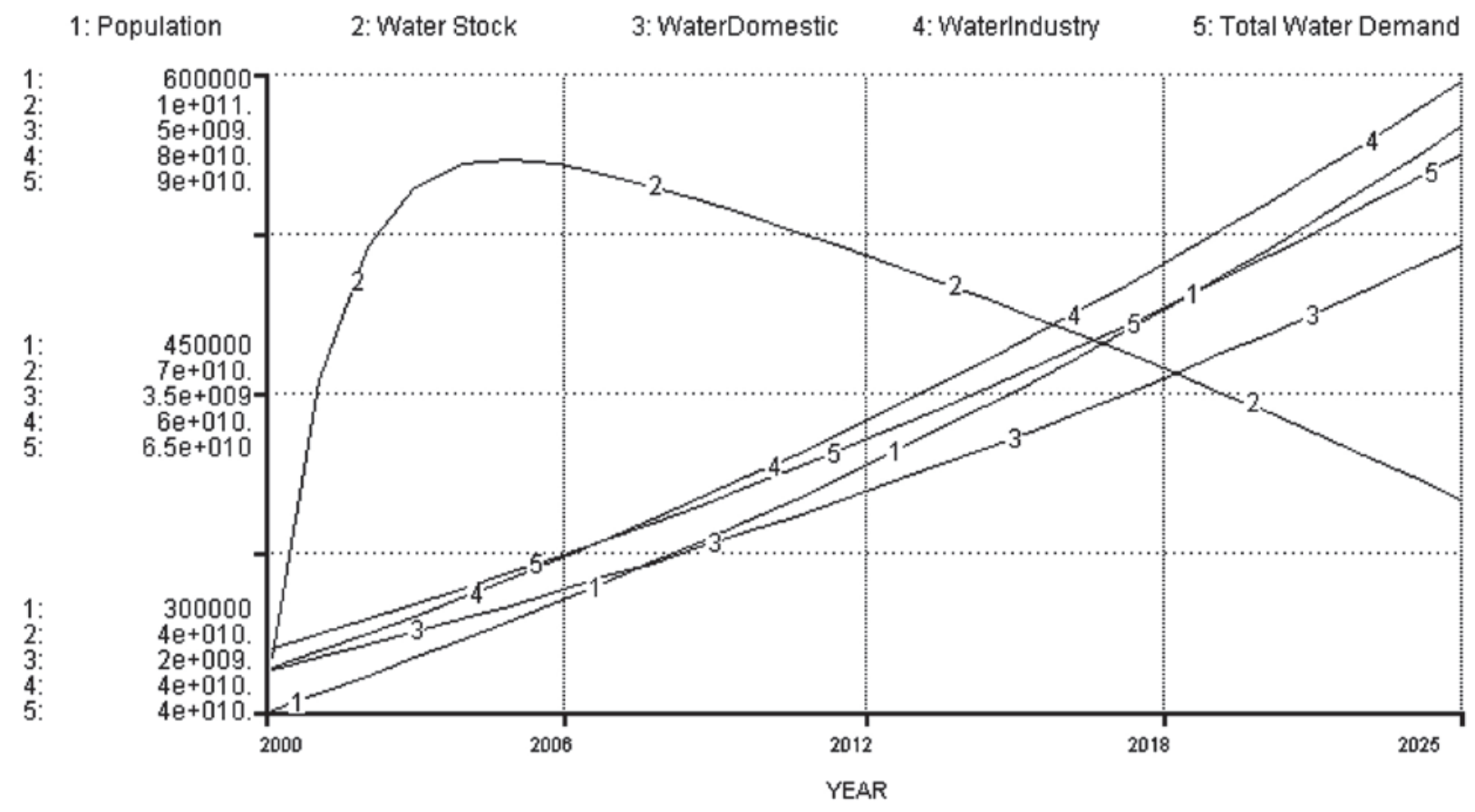

Figure 7. Result of Scenario 1 STELLA Program 
will support services. Water is a basic essential of human life; with the increasing number of people it will also increase the need for water. Specific to the city is a city of Cilegon industrial growth industry will make increasing the number of industries so that the amount of water also needs increased.

Simulation results of scenario 1 water demand model in the city of Cilegon done until 2025, where the increase in the number of people also followed with increasing water needs of the population. Similarly, increasing the number of industries also cause an increase in the water industry needs. The availability of water (water stock) that comes from the results of the model estimated the availability of water supplies would decrease by the year 2025, with a water stock line cross with the TotalWaterDemand that occurred before 2018 years.

To increase the sustainable availability of water in various ways should be tried for everything. According Harmailis (2001), with changes that make alternative is a combination of changes in forest plantations to be $25 \%$, a forest garden and

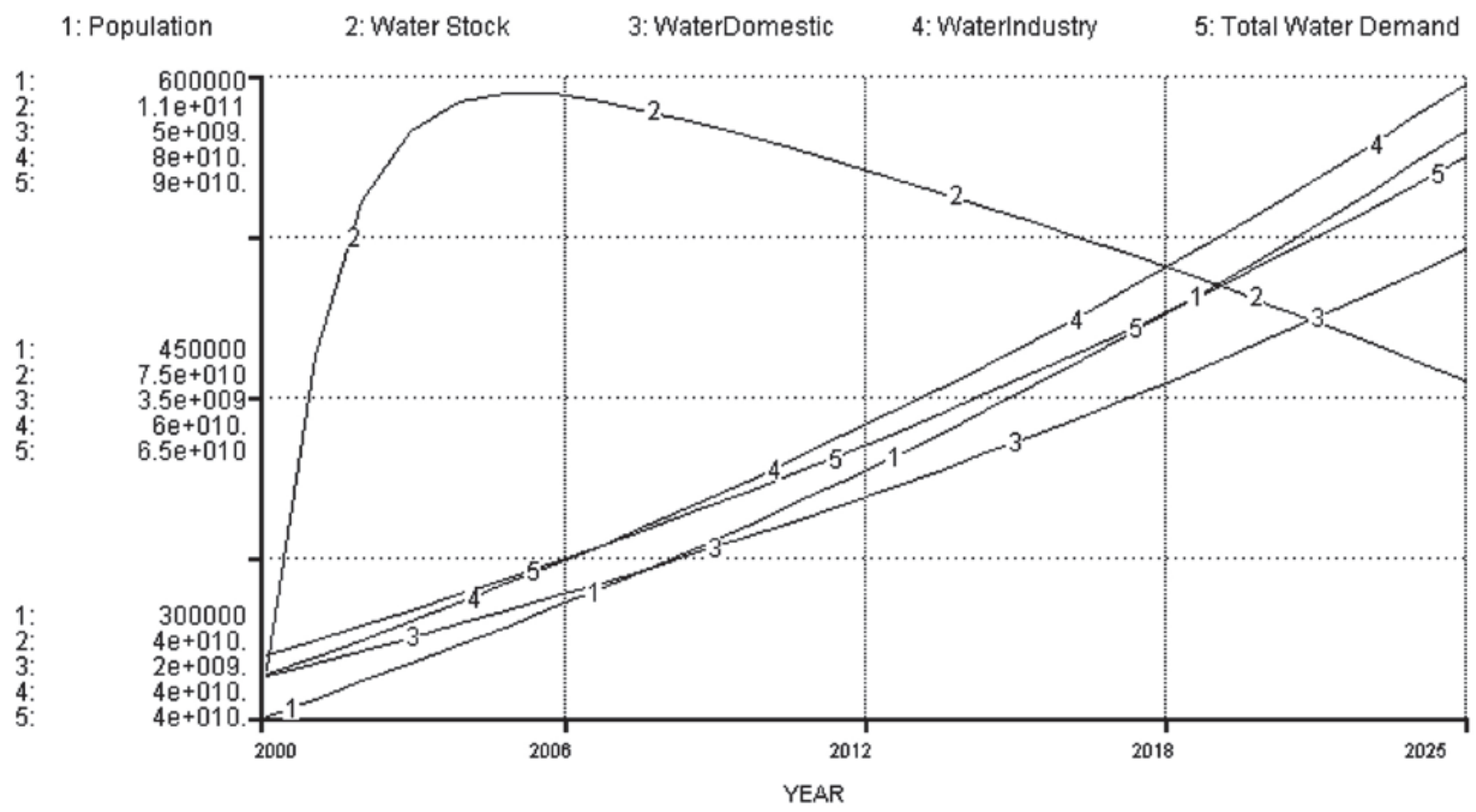

Figure 8. Result of Scenario 2 STELLA Program

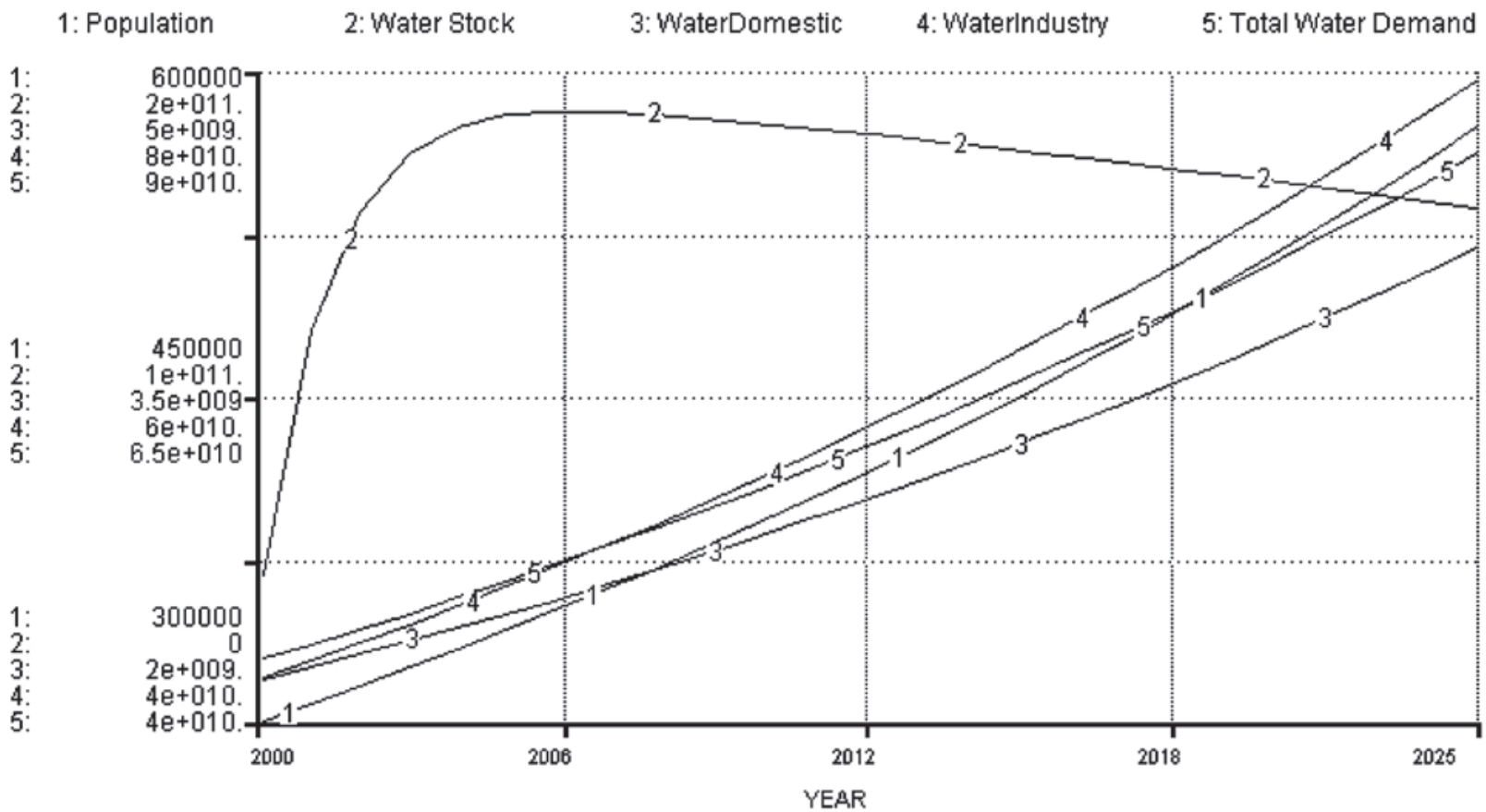

Figure 9. Result of Scenario 3 STELLA Program 
gardens $50 \%$ into $50 \%$ of rice fields will produce the smallest ratio comparison debit Minimun and maximum of $21.73 \%$. Scenario 2 gives the changes that debit minimum $4.3 \mathrm{~m} 3 / \mathrm{det}$ be $4.7 \mathrm{~m} 3 / \mathrm{det}$ which is equivalent to the addition of the availability of debit of $1122 \mathrm{~mm}$.

Figure 8 shows that changes in land use in accordance with scenario 2 the availability of water to the water stock is better than the scenario 1 with cross of water stock line with the TotalWaterDemand that occurred after 2018 years.

Scenario 3 is the implementation of technology improvements to the channel with the pipeline expected to increase the efficiency of water distribution is indicated by Figure 12, can be explained that the water stock line crosses TotalWaterDemand line with the going away after the year 2018.

Changes in land use into forest or field can increase the availability of water. Forests have a high capacity of infiltration so that rainwater does not directly toward the river but is saved as the first ground water reserves. Infiltration capacities of the rice fields have a small but because the management system can save the terraced water longer. Land use gardens have a large flow of surface water so that the rain that falls directly onto the river.

Efforts to maintain the sustainability of water availability should be consider. Action that can be done to Cidanau watershed upland area is to build reservoir and also with terracing. Reservoir development is meant to keep out the water so stored and does not flow directly into the surface of the sea directly to the end. Development terracing useful as building control erosion in mechanical created to cut slopes or out so that the slope can also reduce the flow of the surface directly.

\section{Conclusions}

Model supply and model demand have been developed based on watershed area includes Cilegon City and Cidanau Watershed, Banten Province. Model supply is a modified tank model (model runoff) with input data such as rainfall data and evapotranspiration data with some parameters calibrated. Model validation results for the supply model for the year 2001 values debit $\mathrm{m}^{3} / \mathrm{s}$ a maximum of 39.39 , a minimum of debit and debit $3: 49 \mathrm{~m}^{3} / \mathrm{s}$ an average of $8: 19 \mathrm{~m}^{3} / \mathrm{s}$

Model demand modified based on the water use of the population and water use of industry, model calibrated to get the value of coefficient of water demand. Model validation is done with the water demand model using 2001 data, total water demand for the population $5911 \mathrm{~m}^{3} /$ day and industrial of $95567 \mathrm{~m}^{3} /$ day.

Simulation of water demand for the population and industry in the city of Cilegon, Stella done with the program will show a tendency of a decrease in water availability for the year 2025 as a result of the increased number of residents and industry. The efforts of the water needs of the decline in the city of Cilegon be covering 3 scenarios, scenario 1 using the results with the potential availability of debit $80 \%$ of the water demand until the year 2018; scenario 2 with the changes in land use, $50 \%$ of forest plantations to be and $50 \%$ of the garden into the field of water demand until the year 2018, and scenario 3 of the water demand up to year 2025 approached. To ensure the availability of sustainable water management will need to construct reservoir in upland area and also the development of terracing, so that water availability will continue to be sufficient along with the fulfillment of the increase.

\section{References}

Dumairy. 1992. Economics Water Resources, A Guide to Hydronomics (in bahasa). BPFE. Yogyakarta

Gupta, R., 1989. Hydrologi and Hydraulic System. Prentice Hall Inc. New York.

Harmailis. 2001. Modified Tank Model based on Landuse for sustainable water resources management (in bahasa). Thesis. Graduate School. Institut Pertanian Bogor. Bogor.

Harto, S. 1993. Hydrology Analysis (in bahasa). PT. Gramedia Pustaka Tama, Jakarta.

Linsley, R.K., M.A Kohler and J.J.H Paulus. 1982. Hydrology for Engineers. McGraw Hill Inc. New York.

Manan, S. 1979. Forest and watershed management (in bahasa).. IPB. Bogor.

Pawitan, H. 1995. Analysis method to predict erosion and sedimentation on watershed. Puslitbang Pengairan, Bandung.

Purwanto, M.Y.J. 1995. Water Demand for Industry, Village, and City. Seminar on Water Demand and Developing Country. Tokyo . Japan.

Soerianegara, I. 1978. Natural Resources management. Bagian II. Program Studi Pasca Sarjana. Jurusan PSL. IPB. Bogor. 